\title{
PENGARUH PROFITABILITAS DAN RESIKO KEUANGAN TERHADAP HARGA SAHAM (Studi Kausal Pada PT XL Axiata Tbk)
}

\author{
Dian Maulita ${ }^{(1)}$ \\ maulita.dian@gmail.com \\ Syamsudin $^{(2)}$ \\ Universitas Serang Raya
}

\begin{abstract}
ABSTRAK
PT. XL Axiata Tbk merupakan perusahaan telekomunikasi swasta pertama dan sudah terdaftar di BEI. Seiring dengan berjalannya waktu banyak bermunculan perusahaan telekomunikasi swasta di Indonesia. Hal ini menyebabkan persaingan dalam meperoleh investasi semakin ketat yang berdampak pada kondisi harga saham.

Penelitian ini dimaksudkan untuk menguji bagaimana pengaruh Profitabilitas dan Resiko Keuangan Terhadap Harga Saham Studi Kasus Pada PT. XL Axiata Tbk. Penelitian ini menggunakan riset kuantitatif, yaitu menggunakan sampel yang mencerminkan populasi dalam menguji hipotesis. Data yang digunakan dalam penelitian ini adalah data sekunder yang dipublikasikan oleh Bursa Efek Indonesia berupa Annual Report. Teknik pengumpulan data yang digunakan adalah studi pustaka dimana peneliti menghimpun informasi relevan yang berkaitan dengan topik atau masalah yang akan atau sedang diteliti. Populasi dalam penelitian ini adalah PT. XL Axiata Tbk. Sampel dalam penelitian ini adalah Laporan Keuangan PT. XL Axiata Tbk periode 2007-2017.

Hasil dari penelitian ini adalah (1) Profitabilitas berpengaruh signifikan terhadap harga saham. (2) Resiko Keuangan tidak berpengaruh signifikan terhadap harga saham (3) Profitabilitas dan Resiko Keuangan secara simultan berpengaruh signifikan terhadap harga saham.

Berdasarkan hasil penelitian tersebut diharapkan dapat menjadi referensi bagi manajemen perusahaan dalam pengambilan keputusan dan menjadi referensi penelitian selanjutnya.
\end{abstract}

\section{Kata Kunci : Profitabilitas, Resiko Keuangan, Harga Saham}

\begin{abstract}
PT. XL Axiata Tbk is the first private telecommunications company and is listed on the IDX. Over time, many private telecommunications companies have emerged in Indonesia. This has resulted in tighter competition for investment which has an impact on stock price conditions.

This research is intended to examine how the influence of Profitability and Financial Risk on Stock Prices Case Studies at PT. XL Axiata Tbk. This study uses quantitative research, namely using a sample that reflects the population in testing the hypothesis. The data used in this research is secondary data published by the Indonesia Stock Exchange in the form of an Annual Report. The data collection technique used is literature study where the researcher collects relevant information relating to the topic or problem that will be or is being researched. The population in this study were PT. XL Axiata Tbk. The sample in this study is the financial statements of PT. XL Axiata Tbk for the period 2007-2017.

The results of this study are (1) Profitability has a significant effect on stock prices. (2) Financial risk has no significant effect on stock prices (3) Profitability and financial risk simultaneously have a significant effect on stock prices.

Based on the results of this study, it is hoped that it can become a reference for company management in making decisions and become a reference for further research.
\end{abstract}

Keywords: Profitability, Financial Risk, Stock Price 


\section{PENDAHULUAN}

Awal mula PT. XL Axiata bernama PT. Grahametropolitan Lestari yang didirikan pada tanggal 8 Oktober 1989 yang kemudian diubah menjadi PT. Excelcomindo setelah itu diubah lagi menjadi PT. XL Axiata hingga saat ini. PT XL Axiata merupakan salah satu perusahaan operator telekomunikasi seluler di Indonesia yang mulai beroperasi secara komersil pada tanggal 8 Oktober 1996 dan menjadi perusahaan swasta pertama di Indonesia yang menyediakan jasa layanan telepon seluler. Seiring berjalannya waktu perusahaan seluler di Indonesia kian bertambah. Hal ini yang menyebabkan PT Excelcomindo Pratama Tbk harus memiliki kekuatan dalam mempertahankan kinerjanya sehingga bisa terus exis di bidang usahanya dan meningkatkan kepercayaan para investor untuk menginvestasikan dananya.

Pengevaluasian faktor-faktor yang mempengaruhi peningkatan harga saham dilakukan oleh peurusahaan sebagai usaha untuk menarik investor dan meningkatkan harga saham perusahaan. Menurut Indriyo Gitosudarmo dan Basri (2002:13) harga saham dipasar merupakan perhatian utama dari manajer keuangan untuk memberikan kemakmuran kepada para pemegang saham atau pemilik saham. Menurut Yoga Pratama Putra (2014:2) keputusan berinvestasi merupakan suatu masalah penting yang sering dihadapi oleh para investor. Sehingga investor harus melakukan penilaian dan analisis terlebih dahulu sebelum melakukan pembelian saham apakah saham tersebut layak atau tidak untuk dibeli.

Menurut Hermi dan Kurniawan (2011) salah dalam menentukan saham yang dibeli bisa berakibat fatal bagi para investor karena bisa mengakibatkan kerugian yang besar. Oleh karena itu investor harus dapat menentukan perusahaan mana yang mempunyai pertumbuhan pesat dan memiliki tingkat daya beli masyarakat yang tinggi.

Kualitas nilai saham di pasar modal dapat mempengaruhi tinggi rendahnya minat investor dalam melakukan investasi. Menurut Abid Djazuli (2006:51) kinerja keuangan suatu perusahaan dapat tercermin dari tinggi rendahnya nilai saham suatu perusahaan yang dapat diukur dengan Rasio Keuangan. Menurut Susan Irawati (2006:24) manfaat dari rasio keuangan adalah untuk menentukan prediksi apakah perusahaan tersebut bisa berkembang atau malah perusahaan tersebut gulung tikar. Salah satu rasio yang dapat digunakan adalah rasio profitabilitas yaitu rasio yang digunakan untuk mengukur atau menilai kemampuan suatu perusahaan dalam mencari keuntungan. Rasio Profitabilitas terdiri atas NPM (Net Profil Margin), ROA (Return On Asset), ROE (Return On Equity), ROI (Return OnInvestment). Dalam penelitian ini rasio profitabilitas yang akan diukur adalah dengan menggunakan ROI (Return On Investment) yang merupakan rasio dengan mengukur imbal hasil atas investasi (John Wachowics.2012:180).

Semakin besar ROI maka menunjukan bahwa peningkatan kinerja perusahaan dalam mengelola sumber dana secara efektif untuk menghasilkan laba bersih (profit). Laba bersih yang maksimal selalu menjadi tujuan utama suatu perusahaan. Salah satu hal yang harus diperhatikan dalam keinginan memaksimalkan laba adalah dengan memperhatikan resikonya terutama dalam investasi saham yang akan dibahas oleh peneliti. Karena setiap aktifitas ekonomi selalu memiliki resiko. 
Menurut James Horne (2012 : 117) dalam bukunya "Prinsip-prinsip Manajemen Keuangan" menyatakan bahwa resiko adalah perbedaan dari keuntungan yang diharapkan Apabila membahas mengenai resiko keuangan, maka tidak lepas dari resiko investasi yang berkaitan dengan sekuritas

Untuk mengetahui perusahaan tersebut mempunyai tingkat resiko tinggi atau rendah dapat dilihat dari nilai Z-Score. Metode Altman Z-Score adalah model analisis yang memiliki tingkat ketepatan yang relatif dapat dipercaya yang berfungsi sebagai alat dalam memprediksi kebangkrutan suatu perusahaan. Oleh karena itu analisis ini dapat digunakan untuk mengukur tingkat risiko keuangan suatu perusahaan. Analisis resiko keuangan merupakan alat bantu untuk mendapatkan informasi mengenai kondisi keuangan dengan hasil yang telah dicapai melalui pemilihan strategi perusahaan yang akan digunakan (Denny : 2017).

\section{TINJAUAN PUSTAKA}

\section{Harga Saham}

Menurut Irham Fahmi, (2018:270) saham merupakan tanda bukti penyertaan kepemilikan modal / dana pada suatu perusahaan yang tertulis dalam kertas berupa nilai nominal, nama perusahaan dan diikuti dengan hak dan kewajiban yang dijelaskan kepada setiap pemegangnya.

Menurut Suad Husnan dan Eny Pudjiastuti (2004 : 151) Harga saham adalah nilai sekarang (present value) dari penghasilan yang akan diterima oleh pemodal dimasa yang akan datang. Sedangkan menurut Jogiyanto (2008 : 143) harga saham adalah harga yang terjadi dipasar bursa pada saat tertentu dan ditentukan oleh pelaku pasar.

Menurut Panji Anoraga (2001) harga saham didefinisikan sebagai harga jual saham ketika terjadi tawar menawar antara penjual dan pembeli saham, sehingga nilai pasar saham menunjukan fluktuasi dari harga saham tersebut. Tinggi rendahnya harga saham dipasar modal memberikan daya tarik bagi para investor atau calon investor baik individu maupun kelembagaan. Hal ini lebih disebabkan karena tinggi rendahnya harga saham akan memberikan keuntungan bagi pemodal yang disebut sebagai capital gain.

Variabel dependen atau variabel terikat yang digunakan pada penelitian ini adalah harga saham XL Axiata yang terdaftar di Bursa Efek Indonesia (BEI) antara tahun 2007 sampai dengan tahun 2017. Data yang digunakan merupakan data historis yang disesuaikan dengan periode penelitian.. Harga saham yang digunakan sebagai dasar perhitungan adalah harga saham rata-rata XL Axiata pada saat penutupan (Closing Price) dan setelah tanggal publikasi pada laporan keuangan perbankan di BEI Periode 2007 - 2017.

\section{Profitabilitas}

Profitabilitas adalah kemampuan perusahaan dalam menghasilkan laba selama periode (Munawir, 2014: 33). Sedangkan Brigham dan Houston (2011:107) menyatakan bahwa "rasio profitabilitas akan menunjukkan efek dari likuiditas, manajemen aktiva, dan utang pada hasil operasi". Rasio ini digunakan untuk mengetahui kemampuan perusahaan dalam menghasilkan laba atau seberapa efektif pengelolaan perusahaan oleh manajemen. 
Menurut Kasmir (2014:202) Return On Invesment atau Return On Assets merupakan kemampuan perusahaan menghasilkan laba dari aktiva yang digunakan. Dengan mengetahui rasio ini, dapat menunjukkan seberapa besar efisiensi perusahaan dalam memanfaatkan aktivanya pada kegiatan operasional perusahaan.

Analisa ROI ini sudah merupakaan teknik analisa yang lazim digunakan oleh pimpinan perusahaan untuk mengukur efektivitas dari keseluruhan operasi perusahaan. ROI itu sendiri adalah salah satu bentuk dari rasio profitabilitas yang dimaksudkan untuk dapat mengukur kemampuan perusahaan dengan keseluruhan dana yang diinvestasikan dalam aktiva yang digunakan untuk operasi perusahaan untuk menghasilkan keuntungan.

\section{Resiko Keuangan}

Menurut Irham Fahmi (2014 : 357) mendefinisikan Risiko sebagai bentuk keadaan ketidakpastian tentang suatu keadaan yang akan terjadi dimasa yang akan datang dengan keputusan yang diambil berdasarkan berbagai pertimbangan pada saat ini. Pada bukunya Brigham dan Houston (2011:164) menjelaskan bahwa risiko keuangan merupakan suatu tambahan risiko bagi pemegang saham biasa yang diakibatkan oleh penggunaan leverage keuangan. Leverage keuangan mengacu pada penggunaan sekuritas yang memberikan penghasilan tetap (hutang dan saham preferen).

Menurut Hanafi (2010 : 656 ) Untuk memprediksi potensi terjadinya kebangkrutan perusahaan harus dapat menganalisis resiko keuangan salah satunya dengan menggunakan metode Altman Z-Score. Metode ini berfungsi sebagai model analisis yang bertujuan untuk memprediksi kebangkrutan perusahaan dengan tingkat ketepatan yang relative dapat dipercaya. Analisis resiko keuangan sangatlah membantu manajemen dalam mengetahui kinerja bisnisnya. Sehingga diharapkan dengan adanya analisis resiko keuangan perusahaan dapat memperoleh informasi yang berkaitan dengan posisi keuangan yang menggambarkan hasil yang telah dicapai melalui pemilihan strategi perusahaan yang akan diterapkan.

Untuk dapat menganalisis resiko keuangan sebelumnya dilakukan pengolahan data dengan cara menghitung, adapun rumus yang dapat dihitung sebagai berikut:

1. Working capital to total asset

Dimaksudkan disini adalah analisis antara aktvia lancar (Current Asset) dengan hutang lancar (Current Liabilities).

\section{Retained Earning To Total Asset}

\section{Moda lkerja \\ $\overline{\text { Total aktiva }}$}

Retained disini adalah laba ditahan atau laba yang tidak dibagikan, Retained Earning To Total Asset merupakan kemampuan perusahaan dalam menghasilkan keuntungan pada periode tertentu yang ditinjau dari kemampuan perusahaan dalam mendapatkan laba dibandingkan dengan kecepatan perputaran Operating Asset sebagai ukuran efisiensi usaha. Perhitungan ini mengatur akumulasi laba selama perusahaan beroperasi yang memungkinkan untuk memperlancar akumulasi laba ditahan atau laba yang tidak dibagikan.

Laba ditahan

Total aktiva 


\section{Earning Before Interent And Tax (EBIT) To Otal Asset}

Merupakan indikator yang dapat digunakan dalam mendeteksi adanya masalah pada kemampuan perusahaan.

\section{Market Value Equity}

\section{Laba operasi \\ Total aktiva}

Merupakan perhitungan yang mengukur kemampuan perusaha andalam memberikan jaminan terhadap setiap hutangnya melalui modal sendiri yang mencakup jumlah equitas dan total hutang.

\section{Sales To Total Liabilities}

\section{Jumlah ekuitas}

$\overline{\text { Jumlah hutang }}$

Merupakan perhitungan untuk mengukur kemampuan manajemen dalam menggunakan aktiva untuk menghasilkan penjualan.

\section{Penjualan}

Setelah semua perhitungan diperoleh kemudian dimasukan kedalam rumus (Hanafi, 2010 : 656), yaitu:

$$
\mathrm{Z}=1.2\left(\mathrm{Z}_{1}\right)+1,4\left(\mathrm{Z}_{2}\right)+3.3\left(\mathrm{Z}_{3}\right)+0,6\left(\mathrm{Z}_{4}\right)+1.0\left(\mathrm{Z}_{5}\right)
$$

Untuk mengetahui perusahaan tersebut mempunyai tingkat resiko tinggi atau rendah dapat dilihat dari nilai Z-Score, yaitu jika:

1. Nilai Z-Score lebih kecil atau sama dengan 1.81 artinya perusahaan mengalami kesulitan keuangan dan mempunyai resiko tinggi

2. Nilai Z-Score antara 1.81 sampai 2.99 artinya perusahaan dianggap berada pada daerah abu abu (grey area). Pada kondisi ini, perusahaan mengalami masalah keuangan yang harus ditangani dengan penanganan manajemen yang tepat. Jika terlambat penanganannya perusahaan dapat mengalami kebangkrutan.

3. Nilai Z-Score lebih besar dari 2.99 artinya bahwa perusahaan berada dalam keadaan sehat sehingga mempunyai tingkat resiko yang rendah

\section{HIPOTESIS PENELITIAN}

H1 : Profitabilitas berpengaruh signifikan terhadap harga saham.

H2 : Risiko keuangan berpengaruh signifikan terhadap harga saham.

H3 Profitabilitas dan Risiko keuangan secara simultan berpengaruh signifikan terhadap harga saham.

\section{METODE PENELITIAN}

Penelitian ini menggunakan riset kuantitatif, yaitu dengan melakukan pengujian hipotesis dengan menggunakan sampel yang mencerminkan populasi. Data yang digunakan dalam penelitian ini adalah data sekunder yang dipublikasikan oleh Bursa Efek Indonesia berupa Annual Report. Teknik pengumpulan data yang digunakan adalah studi pustaka dimana studi ini dilakukan oleh peneliti untuk menghimpun informasi yang relevan dengan topik atau masalah yang akan atau sedang diteliti. Populasi dalam 
penelitian ini adalah PT. XL Axiata Tbk. Sampel dalam penelitian ini adalah Laporan Keuangan PT. XL Axiata Tbk periode 2007-2017. Teknik pengumpulan data yang dilakukan dengan 2 metode : (1) teknik study kasus dan (2) teknik dokumentasi. Analisis yang digunakan pada penelitian ini diawali dengan analisis statistik deskriptif, uji asumsi klasik yang terdiri dari uji normalitas, uji Heterokedastisitas, uji multikolonieritas, dan uji autokorelasi, kemudian dilanjutkan dengan analisis regresi liniear berganda, dan pengujian

\section{Coefficients $^{\mathrm{a}}$}

\begin{tabular}{|c|c|c|c|c|c|c|c|}
\hline \multirow[b]{2}{*}{ Model } & \multicolumn{2}{|c|}{$\begin{array}{c}\text { Unstandardized } \\
\text { Coefficients }\end{array}$} & \multirow{2}{*}{$\begin{array}{c}\text { Standardized } \\
\text { Coefficients } \\
\text { Beta }\end{array}$} & \multirow[b]{2}{*}{$\mathrm{T}$} & \multirow[b]{2}{*}{ Sig. } & \multicolumn{2}{|c|}{ Collinearity Statistics } \\
\hline & $B$ & Std. Error & & & & Tolerance & VIF \\
\hline (Constant) & 2207,956 & 1295,406 & & 1,704 & 127 & & \\
\hline $\mathrm{ROI}$ & 273,863 & 108,832 & 698 & 2,516 & ,036 & ,636 & 1,573 \\
\hline RK & 535,160 & 1172,905 & ,126 & 456 &, 660 & ,636 & 1,573 \\
\hline
\end{tabular}

a. Dependent Variable: Saham

hipotesis secara parsial dan simultan.

\section{HASIL PENELITIAN DAN PEMBAHASAN}

\section{Analisis Data}

\section{Persamaan Analisis Regresi}

Dari hasil pengujian asumsi klasik dapat disimpulkan bahwa model regresi dinyatakan baik karena telah terbebas dari uji asumsi klasik yang terdiri dari uji normalitas, uji heteroskedastisitas, uji multikolonieritas dan uji autokorelasi dan layak untuk dilakukan regresi.

Pengujian analisis regresi berganda dilakukan untuk mencari hubungan antara variabel independen dan dependen melalui pengaruh profitabilitas (return on investment) dan resiko keuangan terhadap harga saham. Metode ini dilakukan dengan menggunakan program SPSS vs.21 untuk menguji persamaan regresi

\section{Tabel 1}

\section{Hasil Analisis Regresi Linier Berganda}

Berdasarkan tabel 1 didapatkan persamaan regresi linear berganda sebagai berikut : $\mathrm{Y}=2207,956+273,863 R O I+535,160 \mathrm{RK}+\mathrm{e}$

Persamaan Regresi diatas adalah sebagai berikut :

1. Nilai konstans menunjukkan nilai sebesar 2207,956 yang artinya jika nilai variabel independen nol, maka variabel dependen sebesar 2207,956 dalam hal ini jika nilai Return On Investmen dan resiko keuangan sebesar 0.00 (nol) maka harga saham bernilai sebesar 2207.

2. Nilai variabel $\mathrm{X}_{1}$ Return On Investment menunjukan tanda positif sebesar 273,863 yang berarti setiap kenaikan 1 nilai variabel $X_{1}$ maka meningkatkan harga saham sebesar 273,863 .

3. Nilai variabel $X_{2}$ resiko keuangan menunjukan tanda positif sebesar 535,160 yang berarti setiap kenaikan 1 nilai variabel $\mathrm{X}_{2}$ maka harga saham naik sebesar 535,160. 


\section{Pengujian Hipotesis}

Pengujian hipotesis dilakukan untuk mengetahui apakah variabel independen dalam model regresi berpengaruh terhadap variabel dependen. Dimana pengujian hipotesis menggunakan metode uji $t$ (pengujian secara parsial), uji $f$ (pengujian secara simultan) serta uji korelasi dan koefisiensi determinasi.

\section{Uji t (Pengujian Parsial)}

Uji t dilakukan dengan cara membandingkan $t_{\text {hitung }}$ dengan $t_{\text {tabel }}$ pada $\alpha=0.05$ (one tail) dalam daerah bebas (df) n-k-1 atau 11-2-1 = 8 (n) adalah jumlah kasus dan $\mathrm{k}$ adałah jumlah variabel independen), dimana didapat kesimpulan sebagai berikut :

a. Jika $t_{\text {hitung }}>t_{\text {tabel }}$ maka $\mathrm{H}_{0}$ ditolak dan $\mathrm{H}_{1 \text { atau }} \mathrm{H}_{2}$ diterima

b. Jika $t_{\text {hitung }}<t_{\text {tabel }}$ maka $\mathrm{H}_{0}$ diterima dan $\mathrm{H}_{1}$ atau $\mathrm{H}_{2}$ ditolak

Tabel 2

\section{Hasil Uji t}

\begin{tabular}{|c|c|c|c|c|c|}
\hline \multicolumn{6}{|c|}{ Coefficients $^{a}$} \\
\hline \multirow[b]{2}{*}{ Model } & \multicolumn{2}{|c|}{ Unstandardized Coefficients } & \multirow{2}{*}{$\begin{array}{l}\text { Standardized } \\
\text { Coefficients } \\
\text { Beta }\end{array}$} & \multirow[b]{2}{*}{$\mathrm{t}$} & \multirow[b]{2}{*}{ Sig. } \\
\hline & $\mathrm{B}$ & Std. Error & & & \\
\hline 1 (Constant) & 2207,956 & 1295,406 & & 1,704 & ,127 \\
\hline ROI & 273,863 & 108,832 & ,698 & 2,516 & ,036 \\
\hline Resiko & 535,160 & 1172,905 &, 126 & ,456 & 660 \\
\hline
\end{tabular}

a. Dependent Variable: Saham

Berdasarkan Tabel 2 dapat disimpulkan sebagai berikut :

a) Secara parsial pengaruh profitabilitas (ROI) terhadap harga saham dalam uji $\mathrm{t}$ didapat hasil $t_{\text {hitung }}=2,516$ dan $t_{\text {tabel }}=1,860$ maka $t_{\text {hitung }}>t_{\text {tabel }}(2,516>1,860)$ dan sig 0,05>0,036 sehingga dapat disimpulkan bahwa Ho ditolak $\mathrm{H}_{1}$ diterima yang mempunyai arti profitabilitas (Return On Investment) berpengaruh sígnifikan terhadap harga saham.

b) Secara parsial pengaruh resiko keuangan terhadap harga saham dalam uji t didapat hasil $t_{\text {hitung }}=0,456$ dan $t_{\text {tabel }}=1,860$ maka $t_{\text {hitung }}<t_{\text {tabel }}(0,456<1,860)$ dan sig 0,05 $<0,660$ sehingga dapat disimpulkan bahwa Ho diterima $\mathrm{H}_{2}$ ditolak yang mempunyai arti resiko keuangan tidak berpengaruh signifikan terhadap harga saham.

\section{Uji F (Pengujian Simultan)}

Pengujian simultan (uji F) dilakukan untuk mengetahui pengaruh variabel independen terhadap variabel dependen dimana profitabilitas (Return On Investment) dan 
resiko keuangan terhadap harga saham secara keseluruhan. Uji F dilakukan dengan cara membandingkan $F_{\text {hitung }}$ dengan $F_{\text {tabel }}$ pada $\alpha=0.05$ (one tail) sebagai berikut :

a. Jika $F_{\text {hitung }}>F_{\text {tabel }}$ maka $\mathrm{H}_{0}$ ditolak dan $\mathrm{H}_{1 \text { atau }} \mathrm{H}_{2}$ diterima

b. Jika $F_{\text {hitung } ~} F_{\text {tabel }}$ maka $\mathrm{H}_{0}$ diterima dan $\mathrm{H}_{1 \text { atau }} \mathrm{H}_{2}$ ditolak

Adapun hasil uji $\mathrm{F}$ dapat dilihat pada tabel 3 dibawah ini :

\section{Tabel 3}

\section{Hasil Uji F}

ANOVA $^{\mathrm{a}}$

\begin{tabular}{|l|r|r|r|r|r|}
\hline Model & Sum of Squares & Df & Mean Square & F & Sig. \\
\hline 1 Regression & 16512240,983 & 2 & 8256120,492 & 6,235 &, $023^{\mathrm{b}}$ \\
Residual & 10594003,362 & 8 & 1324250,420 & & \\
Total & 27106244,345 & 10 & & & \\
\hline
\end{tabular}

a. Dependent Variable: Saham

b. Predictors: (Constant), Resiko, ROI

Pada tabel 3 diatas didapat hasil $F_{\text {hitung }}$ sebesar 6,235 kemudian dibandingkan dengan statistik $F_{\text {tabel }}$ yang didapat dari df1- k-1 $(3-1=2)$ dan df2 n-k $(11-2=9)$ sebesar 4,26, yaitu sebagai berikut :

$F_{\text {hitung }}>F_{\text {tabel }}(6,235>4,26)$ dengan tingkat singnifikansi 0,023 lebih kecil dari 0,05 yaitu $0,023<0,05$. Sehingga dapat disimpulkan bahwa profitabilitas (Return On Investment) dan resiko keuangan secara simultan mempunyai pengaruh secara signifikan terhadap harga saham.

\section{Uji Koefisien Determinasi}

Nilai koefisien determinasi ( $R$ Square) menunjukan seberapa besar korelasi atau hubungan antara variabel independen dengan variabel dependen. Koefisiensi korelasi dikatakan kuat apabila nilai $\mathrm{R}$ berada di atas 0.5 dan mendekati 1 .

Koefisien determinasi ( $R$ Square) menunjukan seberapa besar variabel independen menjelaskan variabel dependen. Nilai $R$ Square adalah nol sampai dengan satu, maka variabel independen memberikan semua informasi yang dibutuhkan untuk memprediksi variabel dependen. Sebaliknya, semakín kecil nilai $R$ Spuare, maka kemampuan variabel independen dalam menjelaskan variasi variabel dependen semakin terbatas.

\section{Tabel 4}

\section{Hasil Uji Koefisien Determinasi}

\begin{tabular}{|l|r|r|r|c|}
\multicolumn{7}{|c|}{ Model Summary } \\
\hline Model & $\mathrm{R}$ & $\mathrm{R}$ Square & $\begin{array}{c}\text { Adjusted R } \\
\text { Square }\end{array}$ & $\begin{array}{c}\text { Std. Error of the } \\
\text { Estimate }\end{array}$ \\
\hline 1 &, $780^{\mathrm{a}}$ &, 609 &, 511 & 1150,76080 \\
\hline
\end{tabular}

a. Predictors: (Constant), Resiko, ROI 
Pada tabel 4 diatas nilai $R$ Square adalah 0,609 menunjukan bahwa pengaruhnya kuat antara variabel independen terhadap variabel dependen dimana profitabilitas (Return On Investment) dan resiko keuangan terhadap harga saham sebesar 60,9\% dan sisanya dipengaruhi oleh faktor lain di luar penelitian.

Hasil yang didapat mengenai tingkat pengaruh antar ketiga variabel tersebut digunakan ukuran sebagai mana yang dijelaskan oleh. (Sugiyono dan Agus Susanto, 2015 : 266). Adapun tabel interprestasi terhadap koefisien determinasi, sebagai berikut:

\section{Tabel 5}

Interprestasi Terhadap Koefisien Determinasi

\begin{tabular}{|c|c|}
\hline Besearnya Nilai $\mathbf{R}^{\mathbf{2}}$ & Tingkat Hubungan \\
\hline $0.00-0,199$ & SangatRendah \\
\hline $0,20-0,399$ & Rendah \\
\hline $0,40-0,599$ & Sedang \\
\hline $0,60-0,799$ & Kuat \\
\hline $0,80-0,1000$ & SangatKuat \\
\hline
\end{tabular}

\section{Pembahasan}

\section{Pengaruh Profitabilitas (Return On Investment) terhadap Harga Saham}

Hasil hipotesis dalam uji t (secara parsial) mengenai pengaruh profitabilitas (Return On Investment) terhadap harga saham diperoleh $t_{\text {hitung }}=2,516$ dan $t_{\text {tabel }}=1,860$ pada sign $=$ 0,05 , maka $t_{\text {hitung }}>t_{\text {tabel }}(2,516>1,860)$ yang dapat disimpulkan bahwa Ho ditolak $\mathrm{H}_{1}$ diterima dan mempunyai arti profitabilitas (Return On Investment) mempunyai pengaruh yang sígnifikan terhadap harga saham.

Berdasarkan dari data empiris yang ada dan dari hasil penelitian yang diperoleh, mengindikasikan bahwa tingkat pengembalian profitabilitas (Return On Investment) yang merupakan perbandingan antara laba bersih setelah pajak dengan total asset dapat mempengaruhi secara signifikan terhadap harga saham. Hal ini diperkuat dengan hasil penelitian yang dilakukan oleh Indra R.Onibala (2014) yang menyatakan bahwa variabel return on asset berpengaruh secara signifikan terhadap harga saham dimana perbandingan Return On Asset sama dengan Return On Investment. Sehingga apabila tingkat Return On Investment naik maka mempengaruhi harga saham begitupun jika Return On Investment turun maka akan mempengaruhi harga saham.

Hasil penelitian ini sejalan dengan penelitian sebelumnya yang dilakukan oleh Henny Septiana Amalia (2010) yang hasilnya secara parsial variabel ROI berpengaruh positif dan signifikan terhadap terhadap variabel harga saham, hal ini ditunjukkan dengan nilai signifikansi 0,000 atau $<0,05$. Hasil Penelitian Denies Priatinah (2012) juga menyebutkan bahwa ROI berpengaruh positif terhadap Harga Saham yang dilihat dari hasil uji $t$ dengan $t_{\text {hitung }} 2,699>t_{\text {tabel }} 2,0395$ dan tingkat signifikansinya $0,012<0,05$.

Hasil penelitian ini juga sesuai dengan teori yang dikemukakan oleh ModiglianiMiller yang menyatakan bahwa nilai perusahaan akan tergantung hanya pada laba yang diproduksi oleh aktiva-aktivanya (Brigham dan Houston, 2006 : 70). Hal ini dapat diartikan bahwa dengan memaximalkan penggunaan aktiva yang dimiliki oleh perusahaan 
untuk menghasilkan laba maka dapat meningkatkan nilai perusahaan berupa meningkatnya harga saham karena saham perusahaan direspon positif oleh investor.

\section{Pengaruh Resiko Keuangan Terhadap Harga Saham}

Berdasarkan hasil hipotesis dalam uji t (secara parsial) pengaruh resiko keuangan terhadap harga saham dalam uji $\mathrm{t}$ didapat hasil $t_{\text {hitung }}=0,456$ dan $t_{\text {tabel }}=1,860 \mathrm{sig}=0,05$, maka $t_{\text {hitung }}<t_{\text {tabel }}(0,456<1,860)$ dan sig $0,05<0,660$ dapat disimpulkan bahwa Ho diterima $\mathrm{H}_{2}$ ditolak yang artinya resiko keuangan tidak berpengaruh signifikan terhadap harga saham.

\section{Pengaruh Profitabilitas (Return On Investment) dan Resiko Keuangan terhadap Harga Saham}

Pada hasil uji F (secara simultan) atau ANNOVA (Analisys Of Varians) diperoleh nilai df1=k-1 $(3-1=2)$ dan df2 = n-k $(11-2=9)$ sebesar 4,26, yaitu sebagai berikut :

$F_{\text {hitung }}>F_{\text {tabel }}(6,235>4,26)$ dengan tingkat singnifikansi 0,023 lebih kecil dari 0,05 yaitu $0,023<0,05$. Sehingga dapat disimpulkan bahwa profitabilitas (Return On Investment) dan resiko keuangan secara simultan mempunyai pengaruh secara signifikan terhadap harga saham.

Hasil penelitian ini sejalan dengan hasil penelitian yang dilakukan oleh Denny Kurnia (2017) yang menyatakan bahwa Profitabilitas (ROI) dan Resiko Keuangan secara simultan berpengaruh signifikan yang ditandai dari hasil uji f yaitu $f_{\text {hitung }} 10.027>f_{\text {tabel }} 3.29$ dengan tingkat signifikansi $0,000<0,05$.

Selain itu angka R Square sebesar 60,9\% menunjukkan variabel independen memiliki pengaruh yang kuat terhadap variabel dependen yaitu sebesar 60,9\% dan sisanya sebesar 39,1\% dipengaruhi oleh faktor-faktor lain selain dari Profitabilitas (ROI) dan Resiko Keuangan.

\section{SIMPULAN, IMPLIKASI DAN SARAN}

Berdasarkan hasil penelitian dapat disimpulkan bahwa (1) Profitabilitas berpengaruh signifikan terhadap harga saham. (2) Resiko Keuangan tidak berpengaruh signifikan terhadap harga saham (3) Profitabilitas dan Resiko Keuangan secara simultan berpengaruh signifikan terhadap harga saham.

Berdasarkan hasil penelitian diharapkan dapat menjadi referansi bagi pihak manajemen perusahaan dalam pengambilan keputusan. Bagi peneliti selanjutnya, diharapkan melakukan penelitian lanjutan dengan menggunakan rasio keuangan perusahaan yang berbeda, yang belum dimasukkan dalam model penelitian ini atau dengan menambahkan variabel independen lain yang diduga mempengaruhi harga saham serta memperluas objek penelitian agar informasi yang didapat dari hasil penelitian dapat lebih luas. Keterbatasan dari penelitian ini hanya menggunakan 2 variabel independent, minimnya periode penelitian dan sempitnya objek penelitian yang hanya dilakukan di satu perusahaan saja. 


\section{DAFTAR PUSTAKA}

Abid Djazuli. 2006. Pengaruh EPS, ROI dan ROE terhadap Perubahan Harga Saham Pada Perusahaan Sektor Manufaktur Pada Bursa Efek Jakarta (BEJ). Fordema. Volume 6 No.1: Hal 51-62

Anoraga, Panji. 2009. Manajemen Keuangan. Bandung. Alfabeta.

Brigham, E.P, dan Houston, J.F. 2011. Manajemen Keuangan. Edisi Kedua belas (terjemahan). Jakarta: Salemba Empat

Danies Priatinah dan Prabandaru Adhe Kusuma. 2012. Pengaruh Return On Investment (ROI), Earning Per Share (EPS), dan Dividen Per Share (DPS) terhadap Harga Saham Perusahaan Pertambangan yang terdaftar di Bursa Efek Indonesia (BEI). Jurnal Nominal. Volume 1 No.1 Hal 50-64.

Denny Kurnia. 2017. Investigasi Signifikansi Profitabilitas dan Resiko Keuangan pada Harga Saham Perusahaan Telekomunikasi yang Terdaftar di Bursa Efek Indonesia. Jurnal Sains Manajemen. Volume 3 Nomor 2. Hal 38-55

Fahmi, Irham. 2013. Pengantar Manajemen Keuangan Teori dan Soal Jawab. Edisi Keenam. Bandung. Alfabeta

Hanafi, Mamduh. 2010. Manajemen Keuangan. Edisi Kesatu. Yogyakarta: BPFE

Horne, James C. Van dan John M. Wachowicz. 2012. Prinsip-Prinsip Manajemen Keuangan Edisi Ke-13 Buku 1. Salemba Empat. Jakarta

Henny Septiana Amalia. 2010. Analisis Pengaruh Earning Per Share, Return On Investment, dan Debt To Equity Ratio Terhadap Harga Saham Perusahaan Farmasi Di Bursa Efek Indonesia. Jurnal Manajemen dan Akuntansi. Vol 11. No 2. Hal 98106.

Indrio Gitosudarmo \& Basri. 2002. Manajemen Keuangan. Yogyakarta : BPFE

Irawati Susan. 2005. Manajemen Keuangan. Bandung. Pustaka

Jogiyanto. 2008. Teori Portofolio dan Analisis Investasi. Yogyakarta : BPFE

Kasmir. (2010). Pengantar Manajemen Keuangan. Jakartaa: Kencana Prenada Media Group

Munawir. (2014). Analisis Laporan Keuangan. Yogyakarta: Liberty.

Onibala, Indra R. 2014. "Pengaruh Profitabilitas dan Resiko Keuangan Terhadap Harga Saham Xl Axiata yang Terdaftar di Bursa Efek Indonesia Periode 2007 sampai dengan 2012" Jurnal EMBA. Vol.2. No.1

Suad Husnan dan Enny Pudjiastuti. 2004. Manajemen Keuangan Edisi Kelima. 
e-ISSN 2627-7872/2088-8554

\section{Yogyakarta : UPP AMP YKPN}

Sugiyono, dkk. 2015. Cara Mudah Belajar SPSS dan Lisrel. Alfabeta. Bandung 